\title{
Demographic and Clinical Characteristics of Patients Presenting to the Emergency Department with Snakebite
}

\author{
Acil Servise Yılan Isırması Nedeniyle Başvuran Hastaların Demografik ve Klinik Özellikleri
}

Mustafa Sencer Seğmen', (D) Selen Acehan², (D) Akkan Avci², (D) Müge Gülen², (D) Salim Satar ${ }^{2}$

1-Silifke Devlet Hastanesi, Acil Servis, Mersin, Türkiye. 2- Adana Şehir Hastanesi, Acil Servis, Adana, Türkiye.

\begin{abstract}
Objective: Snake poisonings can cause severe morbidity and mortality. In this study, it was aimed to evaluate arrival times of the patients admitted to the Emergency Medicine Department with a diagnosis of snakebite, bitten areas, clinical manifestations, the need for antivenom doses, the relationship between the length of hospital stay and changes in blood biochemistry.

Materials and Methods: The total number of 34 patients admitted to the Emergency Department of Adana Numune Education and Research Hospital between March 2011 and June 2013 were included in this study. In this study, arrival times of the patients admitted to the Emergency Medicine Department with a diagnosis of snakebite, bitten areas, clinical manifestations, the need for antivenom and their doses, the relationship between the length of hospital stay and changes in blood biochemistry were evaluated.

Results: In our study, 9 (26.5\%) patients were grade 0, 5 (14.7\%) patients, were grade 1, 17 (50.0\%) patients were grade 2, $3(8.8 \%)$ patients were grade 3 . In the clinical follow-up of the patients, the rate of antivenom uptake and the amount of antivenom in patients stay in the hospital for more than 24 hours were significantly higher than the ones that stay in the hospital less than 24 hours. In our study, patients were divided into two groups according to the stages with stage 0-1 and stage 2-3, and doses of antivenoms that they take were compared. The mean dose of antivenom in the group of patients with stage 2-3 was $4.15 \pm$ 2.06 , and this value was $1.83 \pm 1.17$ in patients with stage 0-1.

Conclusions: Despite high-dose antivenom therapy is recommended snake poisonings according to the staging, low-dose antivenom therapy should be considered instead of high-dose antivenom therapy and an additional dose of antivenom could be used according to the clinical follow-up.
\end{abstract}

ÖZET

Amaç: Yllan zehirlenmeleri ciddi mortalite ve morbiditeye neden olabilir. Bu çallş̧ada Acil Tıp Kliniğine yllan ısırması tanisı ile başvuran hastaların hastaneye ulaşma süreleri, usırılan bölgeleri, klinik evreleri, antivenom ihtiyacl ve dozları, hastanede kalış süreleri arasindaki ilişsi ve kan biyokimyasındaki değişikliklerinin değerlendirilmesi amaçlandl.

Gereç ve Yöntem: Çalışmamıza Mart 2011- Haziran 2013 tarihleri arasında Adana Numune Eğitim Araştırma Hastanesi Acil Tip kliniğine yllan isırmast şikayeti ile başvuran 34 hasta dahil edildi. Bu çalışsmada Acil Tip Kliniği'ne yılan ısırması tanısı ile başvuran hastaların hastaneye ulaşma süreleri, usırllan bölgeleri, klinik evreleri, antivenom ihtiyact ve dozları, hastanede kallşs süreleri arasındaki ilişsk ve kan biyokimyasındaki değişiklikler değerlendirildi.

Bulgular: Calıșmamizda Evre 0'da 9 (\%26,5) hasta, Evre 1'de $5(\% 14,7)$ hasta, Evre 2'de 17 (\%50,0) hasta ve Evre 3'de $3(\% 8,8)$ hasta olduğu saptandi. Klinik takiplerinde 24 saatten daha fazla süre hastanede kalan hastalarin antivenom alma orant ve antivenom miktarl 24 saatten daha az hastanede kalanlardan anlaml olarak daha yüksekti. Çalışmamiza alınan hastalar evrelerine göre Evre 0-1 ve Evre 2-3 olarak iki gruba ayrlarak bu iki grubun aldikları antivenom dozları karşılaşttrıld. Evre 2-3 olan gruptaki hastaların

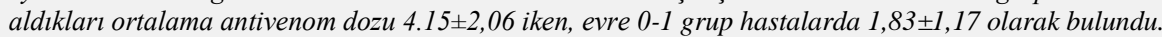

Sonuç: Yllan zehirlenmelerinde evrelemeye göre yüksek doz antivenom tedavisi önerilse de öncelikli olarak anlık yüksek doz yerine düşük doz antivenom tedavi ile başlanabilir ve klinik takibe göre ek doz antivenom tedavi uygulanabilir.

\section{GíRIS}

Çoğu yılan 1sırığı zehirli olmayan yılanlardan kaynaklanır. Dünyada kabaca 3.000 yılan türü bulunur. Bunların sadece \% 15 kadarının insanlar için tehlikeli olduğu kabul edilir1-3. Yılanlar Antartika dışında bütün kıtalarda bulunur. En çeşitli ve yaygın bulunan yılan ailesi, yaklaşık 700 türü olan kırbaç yılanlarıdır (Colubridae). Bu yılanların çoğu insanlar için tehlike oluşturabilecek kadar zehir üretemez, ancak familyanın en az beş cinsi (Dispholidus, Thelotornis, Rhabdophis
Key Words:

Snakebite,

Antivenom,

Emergency

Anahtar Kelimeler:

Yllan istrmast,

Antivenom,

Acil.

ve Tachymenis) insan ölümlerine sebep olmuştur4. Tüm dünyada olduğu gibi Türkiye'de de yılan 1sırmaları önemli bir mortalite ve morbidite nedenidir.

Ülkemizde kırka yakın yılan türü bulunmaktadır. Türkiye'de Çukurova bölgesinde genellikle Vipera ammodytes meridionalis ve Vipera lebetina obtusa tipi zehirli yılanlar bulunmaktadır $(1,2)$. Bu tür yılanlar ciddi sistemik ve doku hasarı yaratacak zehre sahiptirler. Yılan zehri, yaygın damar içi pıhtılaşma gibi sistemik zehirlenme durumuna yol açabileceği

Correspondence: Akkan Avci, MD, Sağlık Bilimleri Üniversitesi, Adana Şehir Eğitim ve Araştırma Hastanesi, Acil Tıp Kliniği, Adana, Türkiye. Email: drakkanavci@gmail.com Phone: +90 5334230369

Cite this article as: Seğmen MS, Acehan S, Avci A, Gülen M, Satar S Demographic and Clinical Characteristics of Patients Presenting to the Emergency Department with Snakebite. Phnx Med J. 2020;2(2):72-78. 


\section{Seğmen et al}

gibi, doku nekrozu etkisiyle ekstremite kaybına da neden olabilir $(3,4)$. Doğru ilkyardım müdahalesi ve etkin bir tedaviyle ölüm oranı düşüktür. Bu çalışmada Acil Tıp Kliniğine yılan ısırması tanısı ile başvuran hastaların hastaneye ulaşma süreleri, 1sırılan bölgeleri, klinik evreleri, antivenom ihtiyacı ve dozları, hastanede kalış süreleri arasındaki ilişki ve kan biyokimyasındaki değişikliklerinin değerlendirilmesi amaçlandı.

\section{GEREÇ VE YÖNTEM}

Çalışmaya Adana Numune EAH girişimsel olmayan klinik araştırmalar etik kurulundan 24.12.2014 tarih ve 94 karar nosu ile onay alındıktan sonra başlandı. Çalışmamız retrospektif olarak yapıldı. Çalışmamıza Mart 2011 - Haziran 2013 yılları arasında Adana Numune Eğitim ve Araştırma Hastanesi Acil Tıp Kliniğine yılan 1sırması şikayeti ile başvuran ve 16 yaş üzeri olan 34 hasta dahil edildi. Özgeçmişinde Kronik böbrek hastalığ 1 olanlar, bilinen kanama diyatezi olan hastalar, oral antikoagülan kullanan hastalar çalışma dışı bırakıldı. Çalışma kriterlerine uygun hastalar acil servise başvurduklarında, zehirlenmenin evresi tespit edilip, tedavisi bu evrelemeye göre belirlendi.

Çalışmaya dahil edilen hastalarda hastaneye başvuru ve tabuculuklarında alınan hastalarda istenilen laboratuvar tetkikleri şunlardır; Tam kan sayımı (CBC), Protrombin Zamanı (PTZ) ve International Normalized Ratio (INR): Aktive Parsiyel Tromboplastin zamanı (APTT): Fibrinojen, Glukoz, Kan Üre Nitrojeni (BUN), Alanin Aminotransferaz (ALT), Aspartat Aminotransferaz (AST), Kreatinin (Cr), Laktat Dehidrogenaz (LDH), Sodyum (Na), Potasyum (K), Klor (Cl), Kreatinin Kinaz (CK), Fibrinojen ve CReaktif Protein (CRP) tetkkleri istendi.
Çalışmaya dahil edilen hastalarda istatistiksel analiz 24 saat ve üstünde hastanede kalan hastalar olarak gruplandırılarak yapıldı. Çalışmamızda verilerin tanımlayıcı istatistiklerinde ortalama, standart sapma, oran ve frekans değerleri kullanılmıştır. Değişkenlerin dağılımı kolmogorov simirnov testti ile kontrol edildi. Niceliksel verilerin bağımsız örneklem $t$ test ve ANOVA kullanıldı. Tekrarlayan ölçümlerin analizinde eşleştirilmiş örneklem $\mathrm{t}$ test ve wilcoxon test kullanıldı. Korelasyon analizinde pearson korelasyon analizi kullanıld1. Analizlerde SPSS 21.0 programı kullanıld1.

\section{BULGULAR}

Çalışmamıza Mart 2011-Haziran 2013 tarihleri arasında yılan 1sırığı nedeniyle başvuran toplam 34 olgunun 13'ü $(\% 38,2)$ kadın, 21 'i $(\% 61,8)$ erkek idi. Yaş ortalaması $41.26 \pm 16,29$ yıl olarak saptand1. Olguların hastanede kalış süreleri incelendiğinde; tüm hastaların ortalama hastanede kalış süresi 28,22 $\pm 19,82$ saat olarak saptand1. Klinik olarak Evre 0 olan hastalar acil servisimizde ortalama 18,12 $\pm 14,5$ saat, Evre 1 olan hastalar 20,4 $\pm 12,2$ saat, Evre 2 olan hastalar 29,9 $\pm 17,4$ saat ve Evre 3 olan hastalar 62,0 $\pm 24,1$ saat takip edildi.

Çalışmamızda hastaların yılan ısırması sonrası hastaneye geliş süresi en erken 2. saatte olup en geç vakanın 22. saatte kliniğimize başvurduğu saptandı (ort=5,12 $\pm 3,62$ saat). Kadın ve erkek hastalarda hastanede kalış süresi açısından aralarında istatistiksel olarak anlamlı $(\mathrm{p}=0,375)$ farklılık saptanmadı (Tablo 1).

Çalışmamızda hastaların 1sırılan bölgelere göre alt ekstremite ve üst ekstremite olarak sinıflandırıldı, hastaların \% 61,8 (n=21) 'inin alt ekstremitesinden, $\% 38,2$ 'sinin $(\mathrm{n}=13)$ üst ekstremitesinden 1sırılmış

Tablo 1: Hastanede kalış sürelerinin cinsiyet, ısırılan bölge, antivenom tedavisi ve klinik evrelendirmeye göre değişimi

\begin{tabular}{|c|c|c|c|c|c|c|}
\hline & & \multicolumn{5}{|c|}{ Hastanede Kalış Süresi (Saat) } \\
\hline & & $\mathrm{n}$ & En düşük & En yüksek & Ort. \pm s.s. & $\mathrm{p}$ \\
\hline \multirow{2}{*}{ Cinsiyet } & Kadın & 13 & 7 & 87 & $32,1 \pm 24,7$ & \multirow{2}{*}{0,375} \\
\hline & Erkek & 21 & 5 & 64 & $25,8 \pm 16,3$ & \\
\hline \multirow{2}{*}{$\begin{array}{l}\text { Isırılan bölge } \\
\text { (Ekstremite) }\end{array}$} & Alt & 21 & 5 & 87 & $29,6 \pm 21,6$ & \multirow{2}{*}{0,609} \\
\hline & Üst & 13 & 7 & 58 & $26,0 \pm 17,2$ & \\
\hline \multirow[b]{2}{*}{ Antivenom } & Almadı & 8 & 7 & 54 & $19,7 \pm 14,7$ & \multirow[b]{2}{*}{0,167} \\
\hline & Ald 1 & 26 & 5 & 87 & $30,8 \pm 20,7$ & \\
\hline \multirow{4}{*}{ Evre } & 0 & 9 & 7 & 54 & $18,2 \pm 14,5^{*}$ & \multirow{4}{*}{0,003} \\
\hline & I & 5 & 5 & 35 & $20,4 \pm 12,2 *$ & \\
\hline & II & 17 & 9 & 64 & $29,9 \pm 17,4$ & \\
\hline & III & 3 & 39 & 87 & $62,0 \pm 24,1$ & \\
\hline
\end{tabular}

*Bağımsız örneklem t test / ANOVA (Tukey test) 
Phnx Med J. July, 2020. Volume 2 No 2

Tablo 2: Hastanede kalış sürelerinin cinsiyet, ısırılan bölge, antivenom, tedavisi, toplam aldığı antivenom dozu ve klinik evrelendirmeye göre değişimi

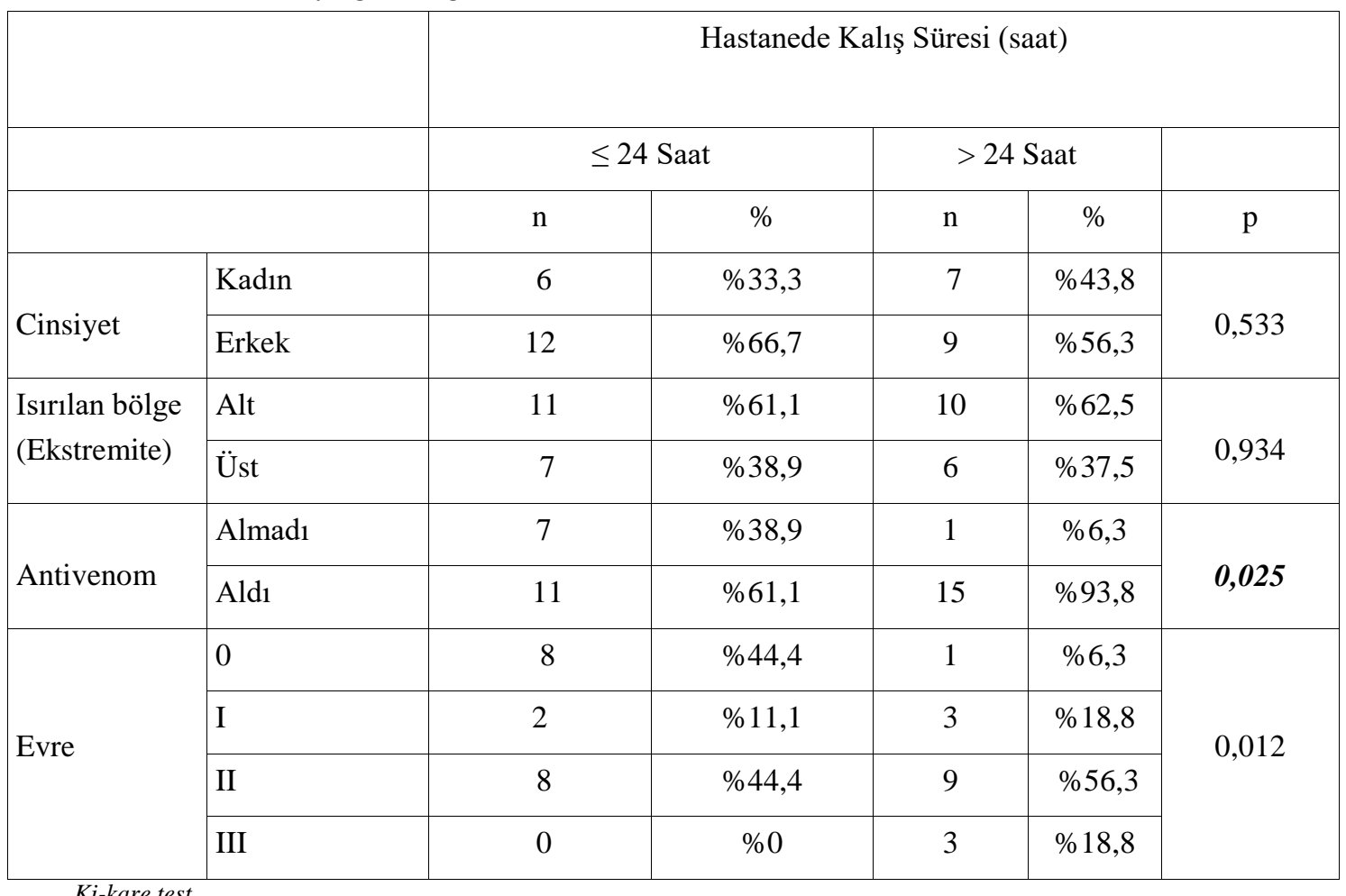

Tablo 3: Evrelendirmeye göre alınan tedavi ve 1sırılan bölge arasındaki ilişki

\begin{tabular}{|c|c|c|c|c|c|c|}
\hline & & \multicolumn{2}{|c|}{ Evre 0-I } & \multicolumn{2}{|c|}{ Evre II-III } & \\
\hline & & \multicolumn{2}{|c|}{ Ort. \pm s.s. $/ \mathrm{n}-\%$} & \multicolumn{2}{|c|}{ Ort. \pm s.s. $/ \mathrm{n}-\%$} & $\mathrm{p}$ \\
\hline \multirow{2}{*}{$\begin{array}{l}\text { Isırılan bölge } \\
\text { (Ekstremite) }\end{array}$} & Alt & 8 & $\% 57,1$ & 13 & $\% 65$ & \multirow{2}{*}{0,643} \\
\hline & Üst & 6 & $\% 42,9$ & 7 & $\% 35$ & \\
\hline \multirow[t]{2}{*}{ Antivenom } & Almadı & 8 & $\% 57,1$ & 0 & $\% 0$ & \multirow{2}{*}{0,000} \\
\hline & Ald 1 & 26 & $\% 42,9$ & 20 & $\% 100$ & \\
\hline \multicolumn{2}{|c|}{ Toplam Aldığı Venom } & \multicolumn{2}{|c|}{$1,83 \pm 1,17$} & \multicolumn{2}{|c|}{$4,15 \pm 2,06$} & 0,015 \\
\hline
\end{tabular}

Ki-kare test/Bağımsız örneklem t test

olduğu saptandı. Alt ekstremite ve üst ekstremite 1sırıklarında hastanede kalış süresi karşılaştırıldığında aralarında istatistiksel olarak anlaml $(p=0,609)$ farklılık saptanmadı (Tablo 1).

Çalışmamızda Evre 0'da $9(\% 26,5)$ hasta, Evre 1'de 5 (\%14,7) hasta, Evre 2'de $17(\% 50,0)$ hasta ve Evre 3'de $3(\% 8,8)$ hasta olduğu saptandı. Çalışmamızda 34 hastaya toplam 95 vial yılan antivenomu kullanıldı. Hastaların evrelerine göre aldıkları antivenom miktarına bakıldığında; Evre 0 hastalara 0,22 $\pm 0,41$

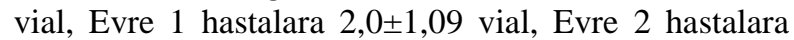
$3,58 \pm 0,84$ vial, Evre 3 hastalara $7,33 \pm 3,29$ vial antivenom verildiği saptand. Hastalara uygulanan ortalama antivenom miktarı 2,79 $\pm 2,34$ idi. Evre 3 grup hastaların hastanede kalıs süresine göre evre 0 , evre I ve evre 2 grup hastalarla karşılaştırıldığında anlamlı $(p=0,003)$ olarak daha yüksek olduğu saptand1. Evre 0, evre 1 ve evre 2 hastalarının ise hastanede yatış sürelerine göre aralarında istatistiksel olarak anlamlı ( $\mathrm{p}$ $>0,05)$ farklılık göstermediği saptandı (Tablo 1).

Çalışmamızda hastaların 8'inin $(\% 23,5)$ antivenom tedavisi almadığı, 26'sının $(\% 76,5)$ antivenom tedavisi almış olduğu tespit edildi. Çalışmaya almış olduğumuz hastaların antivenom tedavisi uygulanıp uygulanmadığı ile hastanede kaldığı süreler kıyaslandığında, anlamlı bir istatistiksel $(\mathrm{p}=0,167)$ farklılık olmadığ $\breve{1}_{1}$ saptand1 (Tablo 1).

Yılan ısıran 34 hastanın 4'üne $(\% 12,06)$ olay anında başkalarınca yanlış ilk yardım (turnike, emme ve kesme gibi) uygulandığı saptand. İlkyardım uygulanmayan 30 hastanın 1sırık yerinde komplikasyon gözlenmedi. Ancak, yanlış ilk yardım uygulanan dört 


\section{Seğmen et al}

hastadan birinde sellülit komplikasyon olarak gözlendi. Hastaların tümünün ısırıldığı ekstremiteleri atele alındı. Ekstremiteler kalp hizasına getirilerek hastalar takibe alındı. Takip boyunca her gün atel açılarak komplikasyon (nekroz, bül, ekimoz ve ödemin ilerlemesi, komprtman sendoromu vb.) gelişimi kontrol edildi. Hastalara günlük yara bakımı uygulandı. Takipler sırasında hiçbir hastamızda kompartman sendromu gelişmedi. Yılan 1sırması kliniğine göre Evre 0 olan hastalara antibiyotik tedavisi uygulanmadı. Evre 1, Evre 2 ve Evre 3 tespit edilenlere ise profilaktik antibiyotik tedavisi uyguland. Hastaların 19 'unda lökositoz ( $\geq 10000 / \mathrm{mm}^{3}$ lökositoz olarak kabul edildi) saptand1. Yedi hastamızda trombositopeni saptandı ( $\leq 150000$ trombositopeni kabul edildi). Hastaların hastaneye kabul esnasindaki ortalama trombosit sayısı $198,79 \pm 79,88$ olarak saptand1. Hastaların müracaat anındaki beyaz küre sayısı ortalama $12070 \pm 4705$ (6.000-22.000) mm3 olarak saptand1. Hastaların 5'inin PTZ değeri 15,5 saniyenin üzerinde idi. Bu hastaların 2'sinin aPTT değeri 35 saniyenin üzerinde saptandi. Aynı zamanda 7 hastanın fibrinojen düzeyleri de düşük bulundu.

Hastanede kalış sürelerine göre $\leq 24$ saat ve 24 saatten fazla takip edilen 2 grup cinsiyet ve 1sır1lan bölge açısından karşılaştırıldığında bu 2 grup arasında istatistiksel olarak anlamlı bir fark olmadığı saptandı ( $p=0,93) .24$ saatten daha fazla süre hastanede kalan hastaların antivenom alma oranı ve antivenom miktarı 24 saatten daha az hastanede kalanlardan anlamlı $(p=0,03)$ olarak daha yüksekti. 24 saatten daha fazla hastanede kalan hastalarda evre 1 ve üstü olma oranı, 24 saatten daha az hastanede kalanlardan anlamlı $(\mathrm{p}=0,01)$ olarak daha yüksekti (Tablo 2$)$.

Çalışmamızda Evre 0-1-2-3 olgularının 1sırılan bölge dağılımları karşılaştırılmış olup; evre 0-1 olan grup ile evre 2-3 olan grup arasında 1sırılan bölge dağılımı açısından anlamlı $(\mathrm{p}=0,643)$ farklılık saptanmadi. Hastaların evrelere göre dağılımı ile antivenom tedavisi alan hasta sayısı karşılaştırıldığında, evre 2-3 olan grubun tamamı $(\mathrm{n}=20, \% 100)$, evre 0 -1 olan grubtaolan hastaların $(n=6, \% 42.9)$ antivenom tedavi aldığ 1 saptanmış olup 2 grup arasındaki fark anlamlı bulundu $(p=0,000)$. Hastaların evrelere göre dağılımı ile toplam aldıkları antivenom tedavisi karşılaştırıldığında; evre 23 olan gruptaki hastaların aldıkları antivenom dozu

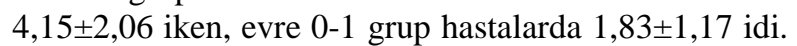
$\mathrm{Bu}$ iki grup arasındaki fark istatistiksel olarak anlamlı bulundu ( $\mathrm{p}=0,015)$ (Tablo 3$)$.

Hastaların hastaneye kabul esnasındaki WBC, PLT; PTZ; INR; APTT; glukoz, üre; K, CK, fibrinojen değerlerinin, taburcu öncesi değerlere göre anlamlı değişim göstermediği saptandı $(\mathrm{p}>0,05)$. Hastaların hastaneye kabul esnasindaki $\mathrm{Hb}$, Hct, Crt; Na, ALT, AST, amilaz, LDH değerlerinin; taburcu öncesi değerlerine göre anlamlı düşüş gösterdiği saptandı $(p=0,02)$. Hastaların kabul esnasındaki CRP değeri $(0,75 \pm 1,65)$, taburcu öncesi CRP değeri $(0,43 \pm 0,61)$ ile karşılaştırıldığında istatistiksel olarak anlamlı bir düşüş
Tablo 4: Hastaların hastaneye kabül ve taburcu öncesi biyokimyasal parametrelerinin değişimi

\begin{tabular}{|c|c|c|c|}
\hline & Geliş Değeri & Çıkış Değeri & \\
\hline & Ort. \pm s.s. & Ort. \pm s.s. & $\mathbf{p}$ \\
\hline WBC & $12,07 \pm 4,70$ & $10,92 \pm 3,29$ & 0,176 \\
\hline HB & $14,49 \pm 1,80$ & $13,17 \pm 1,57$ & 0,000 \\
\hline HCT & $42,71 \pm 4,88$ & $39,12 \pm 4,18$ & 0,000 \\
\hline PLT & $198,79 \pm 79,88$ & $208,79 \pm 62,69$ & 0,200 \\
\hline PTZ & $13,87 \pm 2,36$ & $13,38 \pm 1,41$ & 0,248 \\
\hline INR & $1,14 \pm 0,21$ & $1,09 \pm 0,08$ & 0,171 \\
\hline aPTT & $24,99 \pm 5,52$ & $25,43 \pm 3,69$ & 0,581 \\
\hline Glukoz & $122,15 \pm 40,75$ & $125,76 \pm 39,70$ & 0,165 \\
\hline ÜRE & $29,82 \pm 10,80$ & $27,00 \pm 9,47$ & 0,069 \\
\hline Kreatin & $0,80 \pm 0,22$ & $0,70 \pm 0,14$ & 0,001 \\
\hline NA & $138,47 \pm 2,65$ & $137,18 \pm 2,49$ & 0,003 \\
\hline $\mathbf{K}$ & $4,24 \pm 0,52$ & $4,04 \pm 0,35$ & 0,051 \\
\hline CK & $151,36 \pm 180,36$ & $125,71 \pm 128,70$ & 0,188 \\
\hline ALT & $22,56 \pm 10,25$ & $18,12 \pm 5,80$ & 0,002 \\
\hline AST & $28,06 \pm 10,15$ & $23,00 \pm 7,56$ & 0,000 \\
\hline Amilaz & $50,59 \pm 20,21$ & $42,48 \pm 15,84$ & 0,000 \\
\hline LDH & $194,47 \pm 69,68$ & $172,85 \pm 44,82$ & 0,025 \\
\hline CRP & $0,75 \pm 1,65$ & $0,43 \pm 0,61$ & 0,000 \\
\hline Fibrinojen & $243,61 \pm 55,26$ & $250,48 \pm 48,68$ & 0,250 \\
\hline
\end{tabular}

saptand $\quad(p=0,000) \quad($ Tablo 4). Hastaların kabul esnasındaki laktat dehidrogenaz değeri $(194,47 \pm 69,68$ U/L taburcu öncesi LDH değeri $(172,85 \pm 44,82)$ ile karşılaştırıldığında istatistiksel olarak anlamlı bir düşüş saptand $1(\mathrm{p}=0,000)$.

\section{TARTIŞMA}

Dünyada var olan yılan türlerinin sayısı net olarak bilinmemektedir. Ancak, yaklaşık 3.000 kadar olduğu tahmin edilmektedir (5). Y1lan isırmaları daha çok yaz aylarında karşılaşılan ve ülkemizin Güney ve Güneydoğu Anadolu bölgelerinde sıklıkla saptanan önemli bir morbidite ve mortalite nedenidir (6). Çukurova bölgesinde tarımın temel geçim kaynağ olması yaz mevsiminde yılan 1sırıklarından dolayı acil servislere başvuruları artırmaktadır. Yılan zehirinin önce 1sırılan bölgede ve sonrada tüm vücutta yaygın etkilere yol açmasından dolayı hastalara doğru ve zamanında ilk yardım uygulamak ve etkili bir tedavi uygulamak mortalite oranını düşürmektedir (7). Yılan zehiri birçok zehirli enzim ve proteinin (hemolizin, nörotoksin, nüklotidaz ve kardiotoksin gibi) bir araya gelmesinden oluşur ve bu toksik etkilere ait doku hasarları oluşur. Yılan ısırığının şiddetini belirleyen 
etkenlerler; hastanın yaşı, yılanın ısırdığı yer (baş ile gövde en riskli bölge), vücut kitlesi, hastanın mobil durumu (hareket etmek zehirin emilimini artırır), yılanın ağzındaki patojen ajanlar (gram negatif mikroorganizmalar, özellikle klostridium ve diğer anaerobik ajanlar) ve yılanın büyüklüğüdür (8). Yılan 1sırması nedeniyle acil servise gelen hastaların ilk aşamada normal olmayan yaşamsal bulgularını hızlıca tespit edip düzeltilmek oldukça önemlidir.

Kliniğimize yılan ısırması nedeniyle müracaat eden hastaların \%61,8'i erkek idi. Yaş ortalaması $41,26 \pm 16,29$ y1l olarak saptand. Jarwani ve arkadaşlarının8 yaptığ tespit edilmiştir. Heiner ve arkadaşlarının (9) çalışmasında \%82 oranında erkek hasta müracaatı olduğu bulunmuştur. Hastaların çoğunluğunun kırsal bölgelerde yaşaması ve tarımla uğraşması, bölgemizde erkek cinsiyetin iş gücüne katılım oranının daha yüksek olması erkek cinsiyette daha sık görülmesinin sebebi olabilir.

Hastaların \%61,8'inde alt ekstremite 1sırı ğı tespit edildi. Jarwani ve arkadaşlarının8 yaptığı çalışmada da alt ekstremite 1sırık oranı \%64 olarak bulunmuştur. Zemine en yakın uzvumuz olan alt ekstremitelerimizde yılan ısırığının fazla görülmesi beklenen bir durumdur.

Yılan ısıran 34 hastanın 4'üne (\% 12,06) olay anında yanlış ilk yardım uygulandığı saptandı. İlkyardım uygulanmayan 30 hastanın 1sirılan bölgesinde komplikasyon gözlenmedi. Ancak bilinçsizce ilk yardım yapılan 4 hastanın 1'inde sellülit komplikasyonu gözlendi. McKidney EP ve arkadaşlarının (10) yaptığı çalışmalarda, yılan tarafindan ısıran kişilere nasıl ilk yardım müdahalesi yapılması gerektiği ayrıntılı bir şekilde anlatılmıştır. Michael GC ve arkadaşları (11) ise yaptıkları çalışmada zehirli yılan 1sırıklarında hastalara olay yerinde uygulanan yanlış ilk müdahalenin sonuçlarını belirtmişlerdir. Bu çalışmaya göre uygunsuz ilk yardım doku nekrozu ve ölümle sonuçlanabilir.

Yılan 1sırmalarında antivenom tedaviye ek olarak tetanoz profilaksisi, antibiyotik tedavisi, ekstremite elevasyonu ve istirahat ateli uygulamaları önerilmektedir. Çalışmamızda bulgusu olan tüm hastalarımızın 1sırılan bölgesi atele alınarak, elevasyon yapıldı ve izlendi. Takip boyunca her gün hastanın ateli açılarak nekroz, bül, ve ödem düzeyinin ilerleyip ilerlemediği kontrol edildi. Yara bakımı yapılarak kompartman bulguları yönünden de sık1 bir takip uygulandı. Kliniğimizde takip ettiğimiz hastaların hiçbirinde kompartman sendromu gelişmedi. Kompartman sendromunun klinik bulguları çok iyi bilinmeli ve hasta bu yönden sık1 takip edilmelidir. Kompartman sendromunun klinik bulguları kompartman bölgesindeki kasların pasif gerilmesiyle ağrıluşumu, parestezi, güçsüzlük ve kompartmanın palpasyonuna bağlı ağrı varlığı şeklinde özetlenebilir. Yılan 1sırmaları sonucu görülen lokal bulgular 30 ile 60 dakika içerisinde ortaya çıkmasına karşın kompartman sendromu ilk bir hafta içinde görülebilmektedir.

Yılan tarafindan 1sırılmış tüm vakalara tetanoz proflaksisi uygulaması önerilirken, lokal komplikasyon gelişen hastalar dışında profilaktik antibiyotik verilmesi tartışmalıdır (12). Profilaktik antibiyotik kullanımı daha önceleri her hastaya önerilmekteyken (13), son yıllarda yapılan çalışmalarda rutin olarak profilaktik antibakteriyel verilmesi önerilmemektedir. Tagriweyi DD ve arkadaşlarının (14) yaptığı bir çalışmada ise, ısırılan bölgede doku nekrozu, bül, abse gelişimi, uygunsuz ilk yardım müdahalesi (kesi, emme gibi) varsa mutlaka profilaktik antibiotik kullanılması gerekliliğine değinilmiştir. Clark RF ve arkadaşlarının (15) yaptığı bir çalışma da, her hastaya profilaktik antibiotik uygulamasının gereksizliği anlatılmıştır. Çalışmamıza alınan Evre 0 yılan 1sırığı kliniğine sahip olan hastalara antibiyotik verilmezken, Evre 1, Evre 2 ve Evre 3 saptanan hastalarda profilaktik antibiyotik kullanıldı. Doku ödemi fazla olan, bül, nekroz, gangren, absesi olan, ilk yardım amaciyla uygunsuz müdahalelerde bulunulan hastalarımıza profilaktik antibiyotik tedavisi kullanıldı.

Yilan 1sirmalarında hasta takip ve tedavisini kolaylaştırmak amacıyla klinik evreleme sistemleri kullanılmaktadır. Yılan 1sırmalarında bu evreleme sistemlerinde farklı antivenom dozları önerilmektedir. Roberts JR ve arkadaşlarının (13) geliştirmiş oldukları klinik evrelemede, zehirlenmesi olmayan (Evre 0) ya da hafif doku bulgusu olup da sistemik bulguların gözlenmediği (Evre 1) hastalara antivenom önerilmemiştir. Orta derecede zehirlenmesi olan (Evre 2) hastalara 4-10 vial, şiddetli zehirlenmesi olanlara ise 10-40 vial antivenom verilmesi gerektiğinden bahsedilmiştir. Scharman EJ ve arkadaşlarının (16) bir çalışmasında ise hastalar yine 4 grupta incelenmiş, Evre 0'a 0-4 vial, Evre 1'e 5-9 vial, Evre 2'ye 10-15 vial, Evre 3 olan hastalara ise 15 vial ve üzeri antivenom önerilmiştir. Akpınar ve arkadaşlarının (17) çalışmasında Evre 0 ve Evre 1 hastalara antivenom verilmeden, Evre 2 hastalara ortalama 2,70 $\pm 0,77$ vial, Evre 3 hastalara 4,88 $\pm 1,65$ vial antivenom vererek yeterli klinik etkinlik sağlamışlardır. Juckett $G$ ve arkadaşları (18) ise, yılan 1sırmalarını 5 gruba ayırmışlardır. (Evre 0:zehirlenmesi olmayan, Evre 1: hafif zehirlenme bulguları olan, Evre 2: orta derece zehirlenme tablosu, Evre 3: şiddetli zehirlenme, Evre 4: hayatı tehdit eden zehirlenme). Evre 0'aantivenom önermezken, Evre 1'e 0-5 vial, Evre 2'ye 5-15 vial, Evre 3'e 15-20 vial, Evre 4'e ise 25 vial ve üzeri dozda antivenom önerilmiştir. Antivenomun kime ve ne kadar dozda verileceği uzun yıllardır tartışıldığı gibi kuşkusuz bundan sonra da tartışılmaya devam edecektir. Sonuç olarak yılan 1sırması zehirlenmelerinde birçok yazar farklı antivenom dozları önermektedir $(16,17)$.

Çalışmamızda Evre 0 hastalara 0,22 $\pm 0,41$ vial, Evre 1

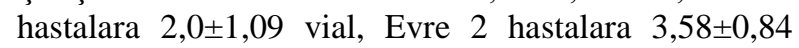




\section{Seğmen et al}

vial, Evre 3 hastalara 7,33 $\pm 3,29$ vial antivenom verildiği saptand. Hastalara uygulanan ortalama antivenom miktarı 2,79 $\pm 2,34$ idi. Kliniğimizde evre 0 tanısı alan hiçbir hastaya antivom verilmedi, 2 hastaya sevk eden sağlık kurumu tarafindan 1'er vial antiveom verildiği saptandı. Çalışmamızda Evre 1 olarak değerlendirilen hastalarımıza antivenom verilmedi. Fakat Evre 1 zehirlenme bulgusu olan 3 hasta kontrollerinde Evre 2' ye ilerledi ve antivenoma ihtiyaç duyuldu. Kliniğimizde düşük doz antivenom tedavi uygulanması sonrası tüm hastalarda yeterli klinik etkinlik sağlandı. Yılan antivenomuna bağlı komplikasyon gelişmedi. Tüm hastalar şifa ile taburcu edildi. Ibister GK ve arkadaşlarının (19) düşük doz antivenom kullanarak yapmış oldukları çalışmada da, takip ettikleri hastalar ölmemiş ve hastalara amputasyon veya fasiyotomi uygulanmamıştır. $\mathrm{Bu}$ çalışmada hastalara ortalama 4 vial (2-5 vial) yılan antiserumu kullanılmıştır (19). Elde ettiğimiz veriler 1şığında düşük doz antivenom tedavi ile yeterli klinik cevabın elde edileceğini düşünmekteyiz.

Çalışmamıza alınan hastalar hastanede kalış sürelerine göre 24 saatten az ve 24 saatten fazla kalanlar olmak üzere 2 gruba ayrılarak karşılaştırıldı. 24 saatten az hastanede kalanların tamamının evre 0 ve 1' de olduğu, 24 satten fazla kalanların evre 1 ve üzeri olduğu tespit edildi. Evre 1'den sonra yılan 1sırığınının lokal ve sistemik bulguları ortaya çıkmaktadır. Buna bağlı olarak da hastaların evresinin artmasıyla kalış süresinin uzaması beklenen bir bulgudur.

Antivenom alan ve almayan hastaların hastanede kalış süreleri karşılaştırıldığında aralarında istatistiksel bir farlılık bulunmadı. Hastaların çoğunluğunun kırsal alandan sevkli olmaları ve gündüz saatleri dışında ulaşım imkanlarının kısıtlı olması nedeniyle taburcu olmak istememelerinden dolayı bu iki grup arasında hastanede kalış süresi arasında fark bulunamamış olabilir.

24 saatten daha fazla süre hastanede kalan hastaların antivenom alma oranı ve antivenom miktarı 24 saatten daha az hastanede kalanlardan anlamlı $(\mathrm{p}=0,03)$ olarak daha yüksekti Bu durumun sebebi 24 saatten daha uzun süre takip edilen hastaların büyük çoğunluğunun Evre 2 ve Evre 3 olmaları ile açıklanabilir. Hastanede kalış süresi ile toplam alınan antivenom dozu arasında anlamlı pozitif korelasyon mevcuttu. Hastaların evresi yükseldikçe verilen antivenom dozu artmaktadır. Buna paralel olarak hastaların hastanede kalış süreleri uzamaktadır. Çalışmamıza alınan hastalar evrelerine göre Evre 0-1 ve Evre 2-3 olarak iki gruba ayrilarak bu iki grubun aldıkları antivenom dozları karşılaştırıldı. Evre 2-3 olan gruptaki hastaların aldıkları antivenom dozu 4,15 $\pm 2,06$ iken, evre 0-1 grup hastalarda $1,83 \pm 1,17$ idi. Bu iki grup arasındaki fark istatistiksel olarak anlamlı bulundu. Yilan 1sırmalarında hastaların evreleri yükseldikçe lokal bulguların ilerleme göstermesi ve sistemik belirtilerin ortaya çıkması beklenmektedir. $\mathrm{Bu}$ durumda hastalardan klinik iyileşme bekleyebilmek için daha yüksek doz antivenoma ihtiyaç duyulmaktadır.

Sonuç olarak, Evrelemeye göre antivenom önerilsede öncelikli olarak düşük doz antivenom tedavi etkinliği takip edilmeli ve gerekirse ek doz antivenom tedavi planlanmalıdır.

Çıkar İlişkisi

Tüm yazarlar çıkar çatışması olmadığını beyan eder.

\section{KAYNAKLAR}

1. Kasturiratne A, Wickremasinghe AR, de Silva N. The global burden of snakebite: a literature analysis and modelling based on regional estimates of envenoming and deaths. PLoS Med. 2008;5:e218.

2. Gold Barry S, Dart Richard C, Barish Robert A. Bites of Venomous Snakes New England Journal of Medicine. 2002; 347(5):347.

3. Russell FE. When a snake strikes. Emerg Med. 1990;22(12):33-43.

4. Mackessy SP. Biochemistry and pharmacology of colubrid snake venoms.Journal of Toxicology-Toxin Reviews. 2002;21(1):43-83.

5. Baran İ, Başoğlu M. Türkiye Sürüngenleri, Kısım 2, Yılanlar Ege Üniversitesi. Basımevi, İzmir, 1998:9-25.

6. Gökel Y, Başlamışlı F, Koçak R. Çukurova yöresinden yılan ısırmaları. Çukurova Üniversitesi Tıp Fakültesi Dergisi. 1997;22:184-8.

7. Warrell DA. Treatment of snakebite in the Assia Passific: A personal view. In: Gopalaksishnakone P, Chou LM, eds. Snake of medical importance singapore venom ad. Toxin Research Group. National University of Singapore. 1990;641-70.

8. Jarwani B, Jadav P, Madaiya M. Demographic, epidemiologic and clinical profile of snake bite cases. J Emerg Trauma Shock. 2013;6(3):199-202.

9. Heiner JD, Bebarta VS, Varney SM, Bothwell JD, Cronin AJ. Clinical Effects and Antivenom Use for Snake Bite Victims Treated at Three US Hospitals in Afghanistan. Wilderness Environ Med. 2013 Jul 16. doi: 10.1016/j.wem.2013.05.001. [Epub ahead of print].

10. McKinney EP. Out of hospital and interhospital management of crotaline snakebite. Annals of Emerg Med. 2001;37(2):168-75.

11. Michael GC, Thacher TD, Shehu MI. The effect of pre-hospital care for venomous snake bite on outcome in Nigeria. Trans R Soc Trop Med Hyg. 2011;105(2):95-101.

12. Al-Durihim H, Al-Hussaini M, Bin Salih S, Hassan I, Harakati M, Al Hajjaj A. Snake bite envenomation: experience at King Abdulaziz Medical City East. Mediatr Health J. 2010;16(4):438-41.

13. Roberts JR, Otten EJ. Snakebites and other reptiles. In: Goldfrank LR, ed. Goldfrenk’ s Toxicolojic Emergencies. Stamford, CT: Appleton \& Lange,1998:1603-23. 
Phnx Med J. July, 2020. Volume 2 No 2

14. Tagwireyi DD, Ball D, Nhachi C. Routine prophylactic antibiotic use in the management of snakebite. BMC Clinical Pharmacology. 2001;1(4).

15. Clark R F, Selden BS, Furbee B. The incidence of wound infection following crotalid envenomation. J Emerg Med. 1993;11:583-6.

16. Scharman E J, Noffsinger D V. Copperhead Snakebites: Clinical severity of local effects. Annals of Emergency Medicine. 2001; 38(1): 55-61.

17. Açikalin A, Gökel Y. Serum IL-6, TNF $\alpha$ levels in snakebite cases occurring in Southern Turkey. Emerg Med J. 2011 Mar; 28(3): 208-11.

18. Juckett G, Hancox G J. Venomous snakebites in the United States: Management review and update. Am Fam Physician. 2002;65:1367-74.

19. Ibister GK, Brown SG, MacDonald E, White J, Currie BJ. Australian Snakebite Project Investigators. Current use of Australian snake antivenoms and frequency of immediate-type hypersensitivity reactions and anaphylaxis. Med J. 2008;188(8):473-6. 